\title{
EduMa
}

\section{Frieze Group Pattern in Buyung Dance Formation}

\author{
Lia Andriani ${ }^{1}$, Arif Muchyidin ${ }^{2}$, Hendri Raharjo ${ }^{3}$ \\ 1,2,3 IAIN Syekh Nurjati Cirebon, Jawa Barat, 45132, Indonesia \\ "Corresponding author: Sunyaragi, Cirebon, Jawa Barat, 45132, Country. e-mail addresses: muchyidin@syekhnurjati.ac.id
}

\section{Article in fo \\ How to cite this article: \\ Andriani, L., Muchyidin, A. \& Raharjo, H (2020). Frieze Group Pattern In Buyung Dance Formation. Eduma: Mathematics Education Learning And Teaching, 9(2), 11 - 24. doi:http://dx.doi.org/10.24235/eduma.v9i2.6960}

Article history:

Received: 07 30, 2020

Accepted: 11 09, 2020

Published: 12, 2020

Copyright (C) 2020 by the author (s) and EduMa: Mathematics Education Learning and Teaching under the Creative Commons Attribution-ShareAlike 4.0 International License.

\begin{abstract}
FRIEZE GROUP PATTERN IN BUYUNG DANCE FORMATION. Buyung dance is a traditional Sundanese dance that reflects the Sundanese community in taking water. Also, the meaning of a pitcher is a kind of tool made of metal or clay often used by some village women in earlier times to take water in rivers, lakes, or ponds. When viewed closely, the Buyung dance formation has mathematical concepts such as the field of geometry, transformation of the geometry, and the counts and measurements made by the dancers in performing the Buyung dance. Besides, each formation also has its philosophical significance. This research is a qualitative study. The researcher directly goes to the field, studies a natural process of discovery through the process, records, analyzes, interprets, and reports, and draws conclusions from the process. Data collected through observation, interviews, and documentation. Based on the research, it was concluded that the beauty of the formation in the pitcher dance was identical to the pattern of the Frieze group. Also, the formation formed has a philosophical meaning that reflects the local wisdom of the local community.
\end{abstract}

\section{Ke y w o r d s :}

Buyung dance, formation, Frieze group 


\section{INTRODUCTION}

Education in Schools has the aim of creating students ready to understand the themes taught. Additionally, education in schools also aims to shape scholars' character (Fitriah et al., 2015). This is in line with the aim of character education within the 2013 curriculum, which is to develop the potential of scholars to become good filial humans, think well, and behave well, build a nation that has the Pancasila character and develop the potential of citizens to possess an attitude of confidence, pride in their nation and country and love humanity (Hartono, 2014; Munjiatun, 2018; Sahroni, 2017; Sumaryati, 2016).

One of the formations of student character is the values contained within the scholars themselves' local wisdom. However, the Indonesian people's cultural value and native wisdom began to be eroded by the swift current of globalization modernization (Amalia et al., 2019; Muchyidin, 2016; Nahak, 2019; Sutarto, 2016). Thus, this has become one of the problems of concern to both the govt and therefore the community because culture is a component that shapes the identity and character of a nation.

Character education is often realized by returning character education, which will impact social morals that contain nobleness of local wisdom values (Sutiyono, 2014; Wahyuningsih, 2017). Therefore, the govt of West Java Province launched a replacement concept for character education called Jabar Masagi. The West Java Masagi Program may be a West Java culturalbased education program. As reported by a variety of online media recently, that generally, West Java Masagi may be a character education that has an impression on social morals that contains the nobility of local wisdom values that are following the requirements and cultural context of every region in West Java (Imilda, 2019; Lukihardianti, 2018).

During this point, education with culture is considered a science that's not interrelated, albeit education is often integrated with culture. An example is that the pitcher dance. Buyung dance is a Sundanese art that will be made like learning mathematics besides art. Researchers will examine that within the pitcher dance, there are various sciences about mathematical concepts.

Buyung dance is never displayed and has begun to be unknown to the general public. Additionally, children today prefer foreign culture and dance. As a result, the pitcher dance is there but not felt. Buyung dance is one among the most dances and must be performed serial of years. there's a beat dance within the movement of movement from one movement to different supported accompaniment music.

Buyung dance is also divided into 5 main formations that have not been left: silk mesh, earth nyakra, bale Bandung, medang kamulan, and Telugu nugu. The formation has various forms like the form of the crescent moon, the circle then forth. Not many of us know that aside from that each movement and pattern in dance follows the flow of the old people's habits and accompaniment music. 
Based on the interview results, every movement within the pitcher dance doesn't have a permanent guide in writing in every movement that's displayed. The dancers only follow the accompaniment and, therefore the philosophy of the dance. If you look carefully, the Buyung Dance formation has mathematical concepts like geometry, geometric transformation, and therefore the counts and measurements made by dancers in performing dances. additionally, each of the movements and formations of Buyung dance also has its philosophical significance.

\section{LITERATURE REVIEW}

a. Buyung Dance

Buyung dance is a typical dance of the Cigugur community, Kuningan Regency. This dance is the main dance in the seren taun ceremony in Cigugur Kuningan Village, West Java (Suharyanto, 2018). This dance tells the story of Cigugur Village girls who are taking water into the river (Pemerintah Kabupaten Kuningan, 2019).

Buyung dance is a Sundanese traditional dance that reflects the Sundanese community in taking water. Besides, the meaning of a pitcher is a kind of tool made of metal or clay which is often used by some village women in earlier times to take water in rivers, lakes, or ponds.

Buyung dance was originally told how the village girls who went down to the river in the pancier ciereng by using a pitcher. Buyung itself is made of pottery that is shaped like a barrel and then burned with a maximum temperature of $100^{\circ} \mathrm{C}$ to produce a strong pitcher (Suharyanto, 2018).
The habit of fetching water with a jug has long been practiced by the community, especially the young women of Kuningan Desa Cigugur with their helpful, lively community, regardless of their social status or beliefs. Now, their habits have drifted, swayed as the wheels of the era continue to roll along with the increasingly evolving technology. All that remains are memories in nostalgic stories.

This dance was created by Emalia Djatikusumah (Reinha, 2019; Widi, 2019). The dance created by Emalia Djatikusumah, the wife of a customary elder, was none other than Djatikusumah in 1969. In the $1969 \mathrm{~s}$, the habits practiced by village women in earlier times could be portrayed and seen in the Kuningan pottery dance.

This dance gets a lot of appreciation from the surrounding community and foreign tourists. This is because some movements seem uncommon to people who are already engaged in this Buyung dance. Dancers consist of several women but sometimes can depend more on how large the ceremony is performed. Dancers usually wear kebaya, a shawl tied around the waist, folded batik cloth tied to the head, hair in a bun, and a pitcher that is placed on the head and a pitcher held (Suharyanto, 2018). To be more clear the author illustrates the clothes worn by dancers using Figure 1 as follows.

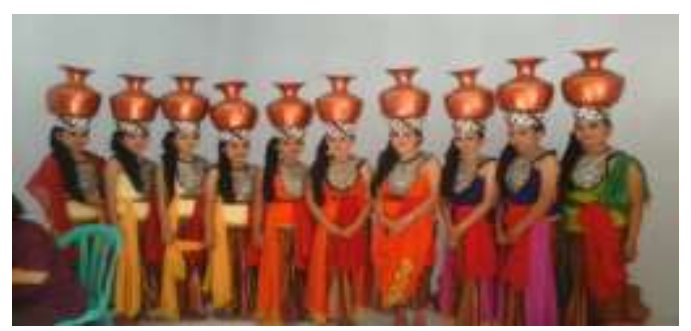


Figure 1. Buyung Dancers Costumes

The appearance of the dancers is not the only attraction of the audience but the dances have a unique movement. A charming movement in this dance when the dancer dances on a pitcher with a pitcher. The dance movements tend to be gentle. Anyone who will see it will be amazed. The dance movement means nyuhun and is close to the parable "where the earth is stood on where the sky is held" (Suharyanto, 2018). The dance movements are as shown in Figure 2.

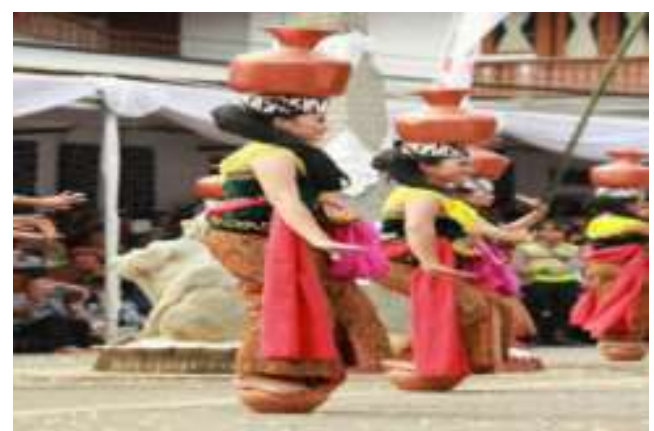

Figure 2. Dancers Dancing Above Jugs

b. Frieze Group

Based on the definitions taken from Drager (2010), a discrete isometric group $G$ is a Frieze Group if all vectors in the lattice are in line (Collinear). Symmetrical groups are called Frieze patterns. If you conjugate $\mathrm{G}$ with a rotation operation, you get a geometrically isomorphic group in the positive $\mathrm{x}$ direction. Frieze patterns are repetitive patterns formed by oneway symmetry. The symmetries are translation, rotation, reflection, or sliding mirror.

According to Umble \& Han (2014) frieze group is a group of symmetry patterns. The several patterns can be grouped into seven types of frieze groups, namely:

1. Pattern 1 (F1)

The symmetry group in pattern 1 only consists of translation.

\section{FFFFFFFFF}

\section{Figure 3. Pattern 1}

In pattern 1, the object only moves from one point to another without any other changes.

2. Pattern 2 (F2)

Pattern 2 symmetry group as in pattern 1 but the isometry used is glide/shear reflection.

\section{$\begin{array}{lllll}F & F & F & F & F\end{array}$ E $\quad \mathrm{E} \quad \mathrm{E} \quad \mathrm{E} \quad \mathrm{E}$}

Figure 4. Pattern 2

In pattern 2, the object is reflected against a certain point and is shifted by several units.

3. Pattern 3 (F3)

The symmetry group for pattern 3 is built by translation and reflection on vertical lines.

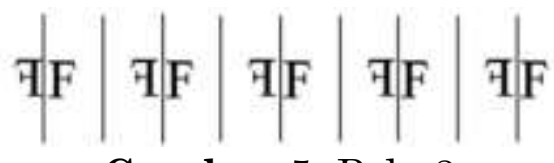

Gambar 5. Pola 3

4. Pattern 4 (F4)

In pattern 4 , the $\mathrm{F} 4$ symmetry group is constructed by translation and rotation of $180^{\circ}$ with the center of $p$, the point between two translations.

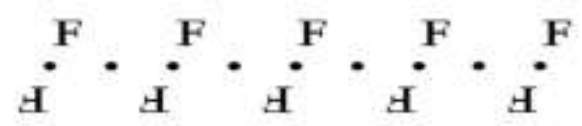

Figure 6. Pattern 4 
5. Pattern 5 (F5)

The symmetrical group F5 for pattern 5 is formed by glide/shear reflection and rotation of $180^{\circ}$.

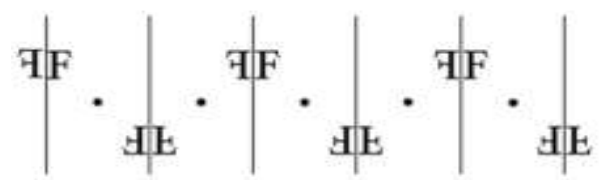

Figure 7. Pattern 5

6. Pattern 6 (F6)

The symmetrical group F6 for pattern 6 is formed by translation and reflection on horizontal lines.

\begin{tabular}{ccccc} 
F & F & F & F & F \\
\hline E & E & E & E & E
\end{tabular}

Figure 8. Pattern 6

7. Pattern 7 (F7)

The F7 symmetry group for pattern 7 is formed by translational, horizontal reflection, and vertical reflection.

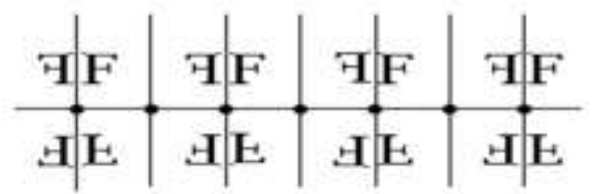

Figure 9. Pattern7

A mathematician named John Conway names each element of the frieze group based on footsteps (Drager, 2010), consider the following picture:

1. Pattern F1 (Hop)

F1 patterns have no isometry other than translation. Figure 10 shows the $\mathrm{F} 1$ pattern.

\section{$14 n+1$}

Figure 10. Hop

2. Pattern F2 (Step)

The F2 pattern, as shown in Figure 11, has a translation and a glide reflection.

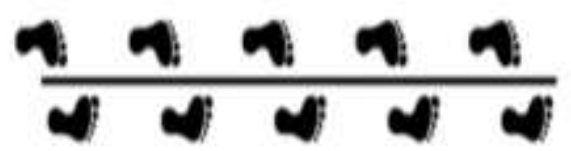

Figure 11. Step

3. Pattern F3 (Sidle)

The F3 pattern has a reflection whose symmetrical axis is parallel to the direction of translation. Figure 11 shows the F3 pattern with vertical translation and reflection.

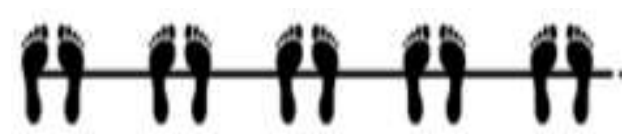

Figure 11. Sidle

4. Pattern F4 (Spinning Hop)

In the $\mathrm{F} 4$ pattern there is a $180^{\circ}$ translation and rotation, as shown in Figure 12 below:

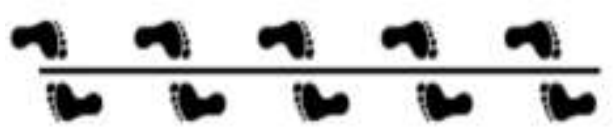

Figure 12. Spinning Hop

5. Pattern F5 (Spinning Sidle) If a pattern has symmetry in the form of translation, a sliding mirror, and $180^{\circ}$ rotation, as shown in Figure 13, then the pattern is called the F5 pattern.

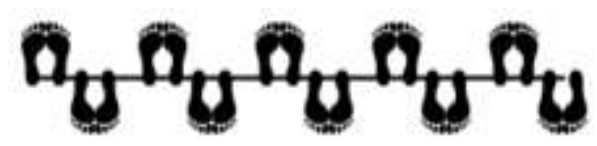

Figure 13. Spinning Sidle 
6. Pattern F6 (Jump)

Pattern F6 contains horizontal translation and reflection as in Figure 14 below:

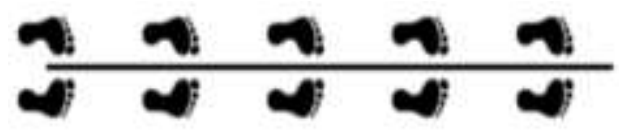

Figure 14. Jump

7. Pattern F7 (Spinning Jump) In the F7 pattern, there are all patterns in F1-F6, namely translation, vertical reflection and horizontal reflection, and rotation.

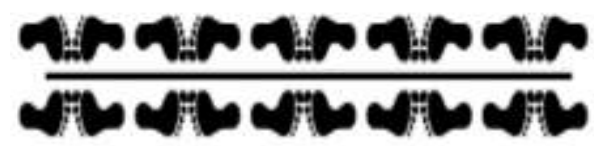

Figure 15. Spinning Jump

To determine the patterns above, follow the steps introduced by Umble \& Han (2014) follows:

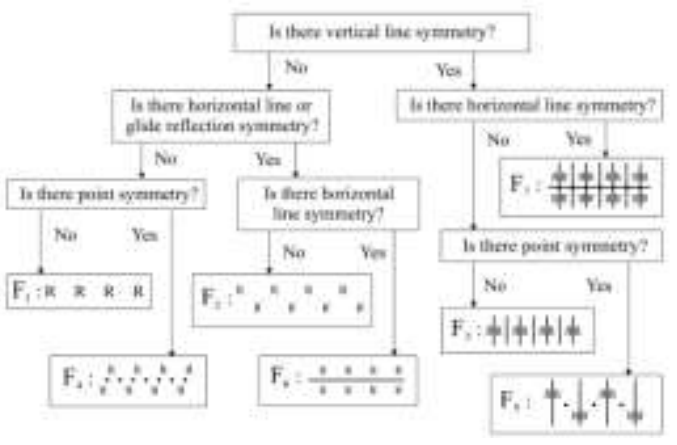

Figure 16. The flow identifies Frieze Group Members

\section{METHODS}

This type of research used in this study is qualitative research. According to Albi Anggito \& Johan Setiawan (2018), Qualitative research is the collection of data in a natural setting to interpret the phenomena that occur. The method according to Meolong (2017), is data collected in the form of words, images, and not numbers and then explained so that they can be drawn. researchers go directly to the field, learn a process or natural discovery through the process, record, analyze, interpret and report, and draw conclusions from the process.

a. Population and Sample

The target/research subjects are Ms. Emalia Djatikusumah as the choreographer and pioneer of the pitcher dance. Mrs. Emalia Djatikusumah was chosen as the research target because besides being a pioneer, she is also a figure who still preserves the dances in Kuningan.

b. Research design

According to Sugiyono (2015), there are three main stages in qualitative research, namely: the description stage or the orientation phase (the researcher describes what is seen, heard, and felt), the reduction stage (the researcher reduces all information obtained in the first stage to focus on a particular problem), and the selection stage (researchers describe the focus that has been set to be more detailed then conduct an in-depth analysis of the focus of the problem).

c. Data Processing Flowchart

Qualitative data analysis is an effort made by working with data, organizing data, sorting it into manageable units, synthesizing it, searching and finding patterns, finding what is important and what is learned, deciding what can be told to others (Moleong, 2017). Data analysis techniques used following the type of data collected and data 
collection, this research data analysis is interactive. The step of analysis in this research is domain analysis, taxonomic analysis, component analysis, and theme analysis (Emzir, 2011).

\section{Data Collection and Analysis}

\section{Qualitative}

research

instruments are tools used to collect data. In qualitative research, the instrument is the researcher himself and cannot be replaced by others. The data was collected verbally by the researcher and enriched from the eyesight, hearing, and appreciation of the researcher regarding the Kuningan dance movements.

Data collection techniques used in this study through the following methods:

\section{Observation}

According to Bungin (2011), observation is the ability of a person to use observation through the work of the five senses and is assisted by other senses. The observation method is used to explore data in the form of facts that are actually on the field in a scientific way to get accurate data. In this study, researchers used passive participation observation techniques (Sugiyono, 2015). Researchers come to the place of the person being observed, but not involved in the activity (Almanshur, 2017).

2. Interview

The interview is a meeting between two people, namely between researchers and speakers to exchange information and ideas with questions and answers, so that the meaning of certain topics can be taken (Sugiyono, 2015). The researcher chooses semistructured interviews to obtain data. However, before interviewing, the author first does the interview guidelines that will be used during the actual interview. When selecting the sources the researcher chooses the resource persons who meet the criteria, namely the resource persons who understand the problem under study and the selected informants who are still active subjects in the research target environment and have time to be asked for information.

3. Documentation

Documentation is a record of a valid event. Documents can be in the form of writing, drawings, or monumental works from someone (Sugiyono, 2017). The technique of studying the documents in this research is to study scientific research journals and theses on dance and ethnomathematics as well as photographs and videos obtained during conducting research. The document complements the research data after conducting observations and interviews.

\section{RESULT AND DISCUSSION}

a. Identification of the Buyung Dance Movement Formation

The results of observations in this study that the dance movements are divided into several main floor formations or patterns that have been determined as follows:

1. Medang Kamulang

Medang kamulang is taken from an ancient royal name in Sundanese. Also, Medang Kamulang has a meaning that is the crescent. A crescent moon or a piece shaped like a halfcircle. Therefore, the medang 
kamulang formation is a halfcircle dance. If there are additional moves to the right and left then that is to add an expression. It aims to make the audience not bored seeing it. If there are an additional four straight lines to the front of the dancer then that is a complement to the creativity of the choreographers.

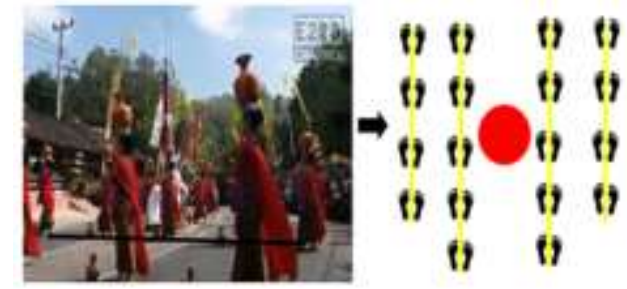

Figure 17. Medang Kamulang Formation

Figure 17 is a picture of the medang kamulang formation with the number of dancers in general, namely as many as eighteen dancers which are divided into four straight rows ahead with the same distance from each other except the middle row because it is blocked by the monument. Four lines of dancers each filled with four to five dancers. The right and left side dancers are occupied by four dancers while the center is occupied by five dancers each.

Figure 17 shows that the dancers line up straight to form a straight line floor pattern. This shows that in the formation of medang kamulang buyung dance using the concept of geometry in the form of a straight line classified into onedimensional geometry. Besides, Figure 17 clearly shows that the dancers are performing the nyuhun pitcher motion with the Kamulang medang formation.

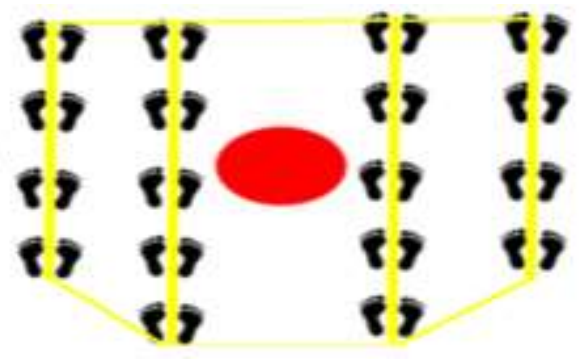

Figure 18. Hexagons in the Medang Kamulang Formation

If a line is drawn from each point of the dancer's position on the side it will form a hexagon floor pattern as shown in Figure 18. After careful observation, the nyuhun pitcher motion in the Kamang Medang Formation contained vertical translation and reflection. This is following Figure 17 with the F3 pattern theory which must have reflections whose symmetrical axes are parallel to the direction of translation. If at the time the dancer performs the motion to place a pitcher on the head with the Paseban monument, it is used as a mirror area, then the nine right dancers are the same as the nine left dancers in both the movement and position of the dancer.

2. Bale Bandung

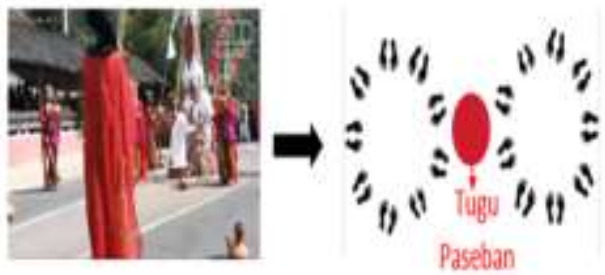

Figure 19. Bandung Bale Formation

If drawn curved lines from each position of the dancer's position will form a circular floor pattern. Figure 19 shows that 
the dancers line up in a circle in a two-circle floor pattern. It shows that in the formation of the bale Bandung dance using the concept of geometry in the form of a circle that is classified into two-dimensional geometry.

Reflection is an operation reflecting an object with a line as a mirror plane. After further observation, the formation of Bale Bandung has the nature of reflection. In this context, if the Paseban monument is a mirror on the $\mathrm{Y}$ axis, it reflects on the bale Bandung formation on the Y-axis

Figure 19 is a reflection of the bale Bandung formation. In this context, when a dancer performs a bale Bandung formation with a paseban monument into a mirror plane, the nine right dancers are the same as the left dancers in both the movements and positions of the dancers.

The purpose of dancers doing bale Bandung formations with the shape of two reflective circles is to describe the existence of a life partner. There are day and night, there are women and men, there are good and there are bad, and many other things that can be interpreted from a life partner. In this context, it does not mean humans are free to choose. However, to illustrate the nature of the two different characters created by God.
3. Nugu Telu

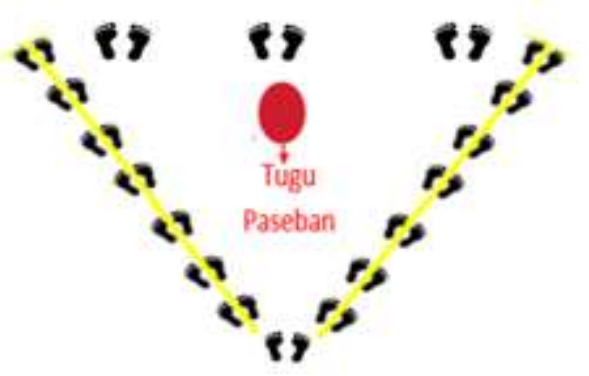

Figure 20. Nugu Telu Formation

Figure 20 is a nugu telu formation with eighteen dancers. In Figure 20 it can be seen that the dancers line up in a straight line pattern. This shows that in the formation of nugu telu buyung dance using geometry concept dance in the form of straight lines classified into one-dimensional geometry. Also, the picture clearly shows that if a line is drawn from each position of the dancer's position it will form a triangular floor pattern.

The nugu telu Formation is a depiction of three phases of life, namely Tri Eka Karsa, consisting of phases of plant life (living but passive), animal life (active but more influenced by instinct), and human life (human life based on reason, sense of life and mind). In the appearance of the nugu telu Formation, it is also a way of realizing humans to recognize the stages of life. According to Ibn Qoyim Isma'il (2009), humans must realize that life consists of levels or levels called Tri Daya Eka Karsa.

4. Jala Sutra

The jala sutra formation is carried out by walking in a 
circle in a small circle and both hands wave the sling which is bound at the center of the circle and between the slings to one another. As a result, silk mesh formations are like blooming flowers.

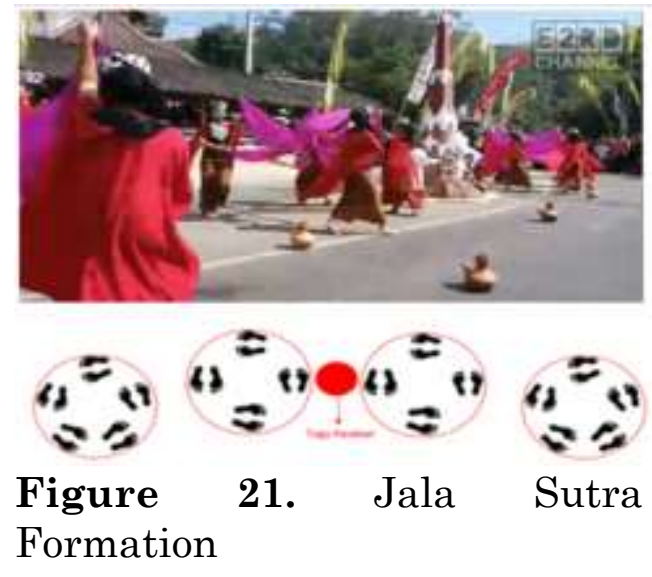

Figure 21 is a jala sutra formation done once. If each small group has drawn a curved line from each position of the dancer's position it will form a circular floor pattern. Figure 21 shows that dancers lined up in a circle form a four circle floor pattern. This shows that in the formation of the jala sutra, Buyung dance uses the concept of geometry in the form of a circle that is classified into twodimensional geometry.

Jala sutra is a combination of two words that have meaning. The word jala (mesh or net) means a tool to catch fish in the form of a round net. The jala is usually used by fishermen who are made of thread or string is woven tenuous. The word sutra is a natural protein fiber that can be woven into textiles with a very soft material. If the two meanings are combined then the jala sutra is around a net made of silk. A net made of silk depicts a woman. A woman is required to have a soft heart like the texture of silk cloth. A woman when facing a problem must be gentle, clear, and in a clean and calm mind. Therefore, the jala sutra formation depicts the softness of a woman symbolized by silk tied together to form a net of circles and played by dancers.

\section{Nyakra Bumi}

Nyakra Bumi formation, which means crossing formation which is done by positioning the line to the front of the Paseban monument. This formation appears once in a pitcher dance. In the formation, the dancer performs a dance move while the pitcher is lifted from the head to fetch water by turning to the right.

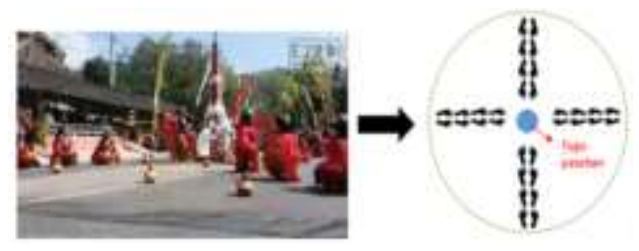

Figure 22. Nyakra Bumi Formation

Figure 22 is a picture of the nyakra bumi formation with the number of dancers in general, as many as sixteen dancers divided into four parts. The division of dancers into four lines crosses each with the same amount. The dancers line up straight to the Paseban monument to form a straight line floor pattern belonging to the concept of geometry in the form of straight lines classified into one-dimensional geometry. Similarly, the distance between dancers one and the other is the same and the distance between 
the lines of one and the other is also the same automatically. The only difference is in the direction of the dancer's position between line one and the other line.

The name Nyakra is taken from the Sundanese language, which means cross or cross. If it means that the chakra is across, then the earth chakra is called the four parts of the wind. This is illustrated in the earth dance nyakra formation to realize that there are four directions of the wind, namely west, north, east, and south.

Formations from Medang Kamulang to Earth Nyakra cannot be replaced. The formation has become a benchmark in the Buyung dance movement. Formations with the terms medang kamulang, nugu telu, bale Bandung, jala sutra, and nyakra bumi are terms that cannot be eliminated in the movements of the pitcher dance.

From the results of the above research, it can be found various types of two-dimensional geometry, namely hexagons, circles, triangles, and longitudinal lines in the floor pattern of a Kuningan pitcher dance formation. the concept of geometry transformation is the frieze group which contains translation, reflection, and rotation in the motion of the dances.

\section{b. Discussion}

Buyung dance is a dance that describes the habits of the ancient people. Basically, according to prince Suryadiningrat (Mulyani, 2016) dance is the movement of all members of the human body arranged in harmony with the rhythm of the music, while the pitcher means a kind of instrument made of metal or clay that is often used by some village women in earlier times to fetch water in the river. So, it can be concluded that the dance of the pitcher means the motion of all members of the human body which are arranged according to the habits of the village women community in the past to fetch water with a tool made of metal or clay and the movement was adjusted to the rhythm of the music. It turns out that the dance of the pitcher is not only a spectacle. However, Buyung dance becomes a guide for social life. Buyung dance depicts the lives of cooperation, mutual harmony, always thank, and if in Sundanese proverbs it means that it is short, saigel sabobot sapihandean. All of that is reflected in the Buyung dance movements.

Researchers found the basic form contained in the determination of the floor pattern in each of the dances dance formation using twodimensional geometry that can produce aesthetic value on the beauty of the dance. In determining what forms are appropriate for the pitcher dance, the researcher determines the depiction of the twodimensional geometry of the floor pattern in each of the pitcher dance formations.

The frieze group is used by researchers to determine the exact measurements and has an element of beauty in the motion of the pitcher dance. The researcher chooses to use the flowchart according to Figure 16 to identify each frieze group pattern in every dance movement. After measuring and grouping according to the 
flowchart, researchers get different results in each part of the dance movements.

The philosophical value of the shape of the floor pattern in every part 3 of the dances forms in the form of differences in the meaning of the guidance on display. First, the circle pattern which has the fingers of a woman's silk sash. The circle on the jala sutra floor pattern is to illustrate the beauty and gentle nature of a woman that every woman must have in dealing with all the problems in the world. Second, the circle of the nyakra bumi floor patterns. In this second circle, the dancer's pattern is clearly on the diameter of the circle which is divided into half it becomes a radius. Thus, the fingers depicted in the picture above illustrate the direction of the compass in life. Third, the circle on the bale Bandung floor pattern. Two circles on the bale Bandung floor pattern mean there is a couple in life. the last hexagon, the hexagonal floor pattern is found in the Medang Kamulang formation which depicts the existence of a kingdom in ancient times and has around sickle meaning.

This explains that the buyung dance movement is created through high historical value and the learning and beauty of the Kuningan dance movement. The movement becomes a spectacle enjoyed by connoisseurs of art and as a guide in life. The concept or element of mathematics that is applied to the culture that develops in the community makes mathematics science that can be applied to various fields of science related to the arts in the community environment which is called ethnomatematics.

Ethnomathematics has a significant role in providing the necessary contextual meaning to abstract mathematical concepts. To accommodate the role of ethnomathematics in mathematics learning, researchers and teachers need to find the link between teaching materials and students' culture to encourage student's development of conceptual learning materials (Makur et al., 2020).

Culture-based mathematics learning is one way that is perceived to make mathematics learning meaningful and contextual which is closely related to cultural communities, where mathematics is learned and will be applied later. Also, culture-based mathematics learning will be an interesting and fun alternative to learning because it allows contextual meaning to occur based on student experiences as a member of a cultural society. Many mathematical concepts can be extracted from a culture (Lestari, 2019).

One culture that can be used as contextual learning is the Kuningan buyung dance. In the buyung dance, there are many mathematical concepts, such as translation, rotation, reflection, center point, and symmetry. In mathematics, the concept of symmetry and translation is known as the concept of the frieze.

The concept of frieze pattern is a concept of subgroups of symmetrical groups that are constructed by translation in one direction. The translation itself has the meaning of moving an object along a straight line with a certain direction and distance (Nggumbe et al., 2018). 
Even though the frieze group has seven patterns, not all formations in the buyung dance meet the criteria of the seven patterns. This is not different from the results of Rahmawati's research on the decorative art of mosques in mosques, which only have the 6th and 7th patterns (Rahmawati et al., 2018).

One of the things that are very dancing to note is that of the five formations in the buyung dance, all of them are centered on a certain point as the center (tugu paseban). The formation that is formed can be formed from the reflection of the Paseban monument, rotation, or translation which results are very symmetrical, so beautiful even though it looks simple.

\section{CONCLUSION IMPLICATION}

AND

Based on the research, it was concluded that the beauty of the formation in the pitcher dance was identical to the pattern of the Frieze group. also, Of the five formations in the buyung dance (Medang Kamulang, Bale Bandung, Telugu Nugu, Jala Sutra, Nyakra Bumi) has a philosophical meaning that reflects the local wisdom of the local community. In each formation, the Paseban monument is the center point of reflection, translation, and rotation, resulting in a symmetrical and very beautiful formation.

The research carried out is limited to the formation of mathematical dance with mathematical formation. If there are researchers who are interested in further, it would be better to make a module as a guide for students and successors of the Kuningan buyung dance.

\section{REFERENCES}

Almanshur, M. (2017). Metode Penelitian Kualitatif. Ar-Ruzz Media.

Amalia, R., Muchyidin, A., \& Izzati, N. (2019). The Implication of Relationship between Designing Woven Motive Skills and Logical Thinking in Mathematics Learning. Journal of Mathematical Pedagogy, 1(1), 1-8. Retrived from https://journal.unesa.ac.id/index.php/JO MP/article/view/7044

Anggito, A., \& Setiawan, J. (2018). Metodologi Penelitian Kualitatif. CV. Jejak.

Bungin, H. B. (2011). Penelitian Kualitatif. Kencana.

Drager, L. (2010). Geometric Transformations and Wallpaper Groups.

Emzir. (2011). Metode Penelitian Kuantitatif \& Kualitatif. Raja Grafindo.

Fitriah, N., Muchyidin, A., \& Sahrodi, J. (2015). Implementasi Model Pembelajaran Matematika Berintegrasi Keislaman Dalam Meningkatkan Karakter Demokrasi Siswa. Eduma: Mathematics Education Learning and Teaching, https://doi.org/10.24235/eduma.v4i2.34

Hartono. (2014). Pendidikan Karakter dalam Kurikulum 2013. Jnana Budaya, 19(2), 259-268. Retrived from https://jurnalbpnbbali.kemdikbud.go.id/ jurnal/index.php/Jnana/article/view/21

Imilda, R. Y. (2019). Dewan Pendidikan Jabar 2019-2024 Segera Elaborasi Program Jabar Masagi. Retrived from http://Disdik.Jabarprov.Go.Id/News/13 45/Dewan-Pendidikan-Jabar-20192024-Segera-Elaborasi-Program-JabarMasagi. http://disdik.jabarprov.go.id/news/1345 /dewan-pendidikan-jabar-2019-2024segera-elaborasi-program-jabar-masagi

Isma'il, I. Q. (2009). Religi Lokal dan Pandangan Hidup. LIPI. 
Lestari, P. (2019). Eksplorasi Etnomatematika Pada Tari Tradisional Zapin Penyengat sebagai Sumber Belajar Matematika Sekolah. Universitas Maritim Raja Ali Haji.

Lukihardianti, A. (2018). Emil Luncurkan Konsep Pendidikan Karakter Jabar Masagi. Republika Online. Retrived from

https://republika.co.id/berita/nasional/p emprov-jabar/18/12/04/pj7n0e423emil-luncurkan-konsep-pendidikankarakter-jabar-masagi

Makur, A. P., Gunur, B., \& Rampung, B. (2020). Exploring Motifs In Towe Songke, Manggaraian Ethnic Woven Fabric, In Mathematics Perspective. SJME (Supremum Journal of Mathematics Education), 4(2), 124133.

https://doi.org/10.35706/sjme.v4i2.345 7

Moleong, L. J. (2017). Metode Penelitian Kualitatif. PT Remaja Rosdakarya.

Muchyidin, A. (2016). Model Matematika Kearifan Lokal Masyarakat Desa Trusmi Dalam Menjaga Eksistensi Kerajinan Batik Tulis. JES-MAT (Jurnal Edukasi Dan Sains Matematika), 2(1). https://doi.org/10.25134/jesmat.v2i1.268

Mulyani, N. (2016). Pendidikan Seni Tari Anak Usia Dini. Gava Media.

Munjiatun. (2018). Penguatan Pendidikan Karakter. Jurnal Kependidikan, 6(2), 334-349.

https://doi.org/10.24090/jk.v6i2.1924

Nahak, H. M. . (2019). Upaya Melestarikan Budaya Indonesia Di Era Globalisasi. Jurnal Sosiologi Nusantara, 5(1), 6576. https://doi.org/10.33369/jsn.5.1.6576

Nggumbe, C. L. B. P., Mayasari, K., \& Jamco, T. H. M. (2018). POLA FRIEZE PADA BATIK PAPUA. Prosiding Seminar Nasional Matematika Dan Pendidikan
Matematika, 44-49. Retrived from http://eproceedings.umpwr.ac.id/index. $\mathrm{php} /$ sendika/article/view/260

Pemerintah Kabupaten Kuningan. (2019). Seni Budaya. Retrived from https://Www.Kuningankab.Go.Id/Wisat a-Budaya/Seni-Budaya.

https://www.kuningankab.go.id/wisatabudaya/seni-budaya

Rahmawati, A., Helmi, \& Fran, F. (2018). FRIEZE GROUP PADA SENI DEKORATIF MASJID. Buletin Ilmiah Math, Stat, Dan Terapannya (Bimaster), 07(1), 23-32. Retrived from

https://jurnal.untan.ac.id/index.php/jbm str/article/view/23583

Reinha, N. (2019). Tari Buyung Refleksi Untuk Generasi Zaman Now. Retrived from

https://www.reinha.com/2017/12/taribuyung-refleksi-untuk-generasi-zamannow/

Sahroni, D. (2017). Pentingnya Pendidikan Karakter Dalam Pembelajaran. Prosiding Seminar Bimbingan Dan Konseling, 1(1), 115-124. Retrived from

http://pasca.um.ac.id/conferences/index .php/snbk

Sugiyono. (2015). Metode Penelitian Pendidikan: Pendekatan Kuantitatif, Kualitatif, dan $R \& D$. Alfabeta.

Sugiyono. (2017). Metode Penelitian Kuantitatif, Kualitatif, dan $R \& D$. Alfabeta.

Suharyanto. (2018). Tari Buyung dan Penjelasannya. Retrived from https://Ilmuseni.Com/SeniPertunjukan/Seni-Tari/TariBuyung\#: :Text=Tari\%20buyung\%20a dalah\%20tarian\%20yang,Sudah\%20dib erikan\%20kepada\%20Sang\%20Pencipt a. $\quad \mathrm{https}: / /$ ilmuseni.com/senipertunjukan/seni-tari/tari-buyung

Sumaryati. (2016). Manajemen Pendidikan Karakter. Tarbawiyah, 13(2), 205-220. https://doi.org/10.21831/jpk.v0i3.2752 
Sutarto, D. (2016). Kearifan Budaya Lokal Dalam Pengutan Tradisi Malemang Di Tengah Masyarakat Modernisasi Di Sungai Keruh Musi Banyuasin Sumatera Selatan. Jurnal Dimensi, 5(3), 2-6. https://doi.org/10.33373/dms.v5i3.54

Sutiyono. (2014). Penerapan Pendidikan Budi Pekerti Sebagai Pembentukan Karakter Siswa Di Sekolah: Sebuah Fenomena Dan Realitas. Jurnal Pendidikan Karakter, O(3), 309-320. https://doi.org/10.21831/jpk.v0i3.2753

Umble, R. N., \& Han, Z. (2014). Transformational plane geometry. In Transformational Plane Geometry. https://doi.org/10.1201/b17787

Wahyuningsih, S. (2017). Lagu Anak Sebagai Media Dalam Mendidik Karakter Anak Usia Dini. Thufula, 5(1), 150-180.

http://dx.doi.org/10.21043/thufula.v5i1. 2356

Widi, H. (2019). Seren Taun, Ritual Seserahan yang Menyimbolkan Persatuan dan Kesatuan. Retrived from https://www.cendananews.com/2019/08 /seren-taun-ritual-seserahan-yangmenyimbolkan-persatuan-dankesatuan.html 